\title{
Clinical and hematological evaluation of Rangelia vitalii-naturally infected dogs in southeastern Brazil
}

Avaliação clínica e hematológica de cães naturalmente infectados por Rangelia vitalii no sudeste do Brasil

Tatiana Didonet Lemos ${ }^{1 *}$; Helena Keiko Toma²; Renata Quintela Assad'; Adrianna Vieira da Silva;

Rafael Gomes Bartolomeu Corrêa ${ }^{3}$; Nádia Regina Pereira Almosny ${ }^{1}$

\author{
${ }^{1}$ Departamento de Patologia e Clínica Veterinária, Universidade Federal Fluminense - UFF, Niterói, RJ, Brasil \\ ${ }^{2}$ Laboratório de Diagnóstico Molecular e Hematologia, Faculdade de Farmácia, Universidade Federal do Rio de Janeiro - UFRJ, Rio \\ de Janeiro, RJ, Brasil \\ ${ }^{3}$ VetLab Análises Clínicas Veterinárias, Itaipava, RJ, Brasil
}

Received March 8, 2017

Accepted June 7, 2017

\begin{abstract}
Rangelia vitalii, a tick-borne piroplasm that infects dogs, has been recently molecularly characterized in Brazil, Uruguay and Argentina. Studies on molecular characterization of these piroplasms in different Brazilian regions are scarce. The aim of this study was to evaluate clinical and hematological changes in dogs caused by $R$. vitalii in the mountainous region of the state of Rio de Janeiro. Blood samples from 36 dogs were evaluated for piroplasms and hematological disorders using light microscopy and molecular analysis. Blood samples from all the animals included in this study were confirmed to be positive for $R$. vitalii through genetic sequencing. Clinical signspresented by 24 of the 36 dogs of the study were evaluated during appointments or hospitalization within private practice. The most frequent clinical disorders in these dogs that were naturally infected with $R$. vitalii were fever, spontaneous cutaneous bleeding and diarrhea. Normochromic non-regenerative anemia and thrombocytopenia were the most common hematological disorders in these $R$. vitalii-positive dogs and therefore should be considered in hematological evaluations on suspected cases.
\end{abstract}

Keywords: Piroplasm, Rangelia vitalii, dogs, PCR, hematological evaluation.

\section{Resumo}

Rangelia vitalii, um piroplasma transmitido por carrapatos que infecta cães, foi sendo recentemente caracterizado molecularmente no Brasil, Uruguai e Argentina. Nas diferentes regiôes brasileiras são escassos os estudos acerca da caracterização molecular destes piroplasmídeos. O objetivo deste estudo foi avaliar as alteraçóes clínicas e hematológicas em cães causadas por $R$. vitalii na regiáo serrana do Rio de Janeiro. Amostras de sangue total de 36 cáes foram examinadas quanto à presença de piroplasmas pela microscopia de luz, alteraçôes hematológicas e análise molecular. Todos os cães do presente estudo foram positivos para $R$. vitalii através do sequenciamento genético. Dos 36 animais positivos para R. vitalii, 24 foram avaliados clinicamente. As alteraçóes mais frequentemente observadas foram febre, sangramento cutâneo espontâneo e diarréia. Anemia normocítica normocrômica arregenerativa e trombocitopenia foram as alteraçôes hematológicas mais observadas em cáes positivos para $R$. vitalii, devendo ser consideradas na avaliaçáo hematológica de cães suspeitos.

Palavras-chave: Piroplasma, Rangelia vitalii, cães, PCR, avaliação hematológica. 


\section{Introduction}

Rangelia vitalii is a protozoon that infects dogs, causing an extravascular hemolytic disorder. It belongs to the phylum Apicomplexa, order Piroplasmida and family Babesiidae. To date, $R$. vitalii has only been described in Brazil, Uruguay and Argentina (LORETTI \& BARROS, 2005; EIRAS et al., 2014; SOARES et al., 2015). This protozoon can be seen as free forms in plasma and in erythrocytes, monocytes and endothelial cell cytoplasm, within cerebral capillaries and in the aorta and jugular vein (LORETTI \& BARROS, 2005). It is easier to view the parasite during fever peaks in blood smears (PESTANA, 1910b; SILVA et al., 2011). It has been shown that the tick Amblyomma aureolatum is the vector responsible for its transmission (SOARES et al., 2014). This tick species also infects wild animals, which are thought to act as reservoirs for $R$. vitalii. Molecular studies have detected $R$. vitalii in the blood of Cerdocyon thous and Lycalopex gymnocercus (SOARES et al., 2014; QUADROS et al., 2015). Rangelia vitalii-infected dogs are found in rural and urban fringe areas, especially in areas close to forest and wilderness (BRAGA, 1935; LORETTI \& BARROS, 2004).

The clinical signs described in dogs with rangeliosis include sadness, fever, apathy and prostration (PESTANA, 1910a; CARINI \& MACIEL, 1914; BRAGA, 1935; POCAI et al., 1998). Jaundice and anemia are also frequently observed. Spontaneous bleeding can occur from ears and skin (PESTANA, 1910b; CARINI \& MACIEL, 1914), which has led to popular naming of the disease as "blood plague" or "nambi-uvú", which means "ear that bleeds" in the indigenous language Tupi Guarani. The skin surface of affected animals can present extensive areas covered by clotted blood, with dark red crusts that become dry with clumped hair (LORETTI \& BARROS, 2004; FRANÇA et al., 2014).

The most common hematological disorders are anemia, ranging from normocytic and normochromic to macrocytic and hypochromic, and thrombocytopenia (FIGHERA et al., 2010; PAIM et al., 2012b). Other abnormalities that have been reported include anisocytosis, polychromasia, Howell-Jolly bodies and reticulocytes (LORETTI \& BARROS, 2004; LORETTI \& BARROS, 2005; FIGHERA, 2007).

Rangelia vitalii is morphologically identical to the piroplasm Babesia vogeli, which also infects dogs. Therefore, making a morphological diagnosis for species differentiation is not viable. Differentiation of these species is done by molecular diagnostics by PCR and genetic sequencing. Genes that amplify piroplasms by partial sequences of the $18 \mathrm{~S}$ rRNA and the heat shock protein 70 (bsp70) genes (SOARES et al., 2011; LEMOS et al., 2012) have been used for parasite DNA detection.

The aim of this study was to evaluate clinical signs and hematological changes in dogs that were found to be positive for $R$. vitalii by PCR and sequencing.

\section{Materials and Methods}

\section{Samples and light microscopy}

This study was approved by the Ethics Committee of the Fluminense Federal University (Universidade Federal Fluminense), under the number 147 . The 36 animals used in this study were selected between October 2009 and November 2013. They were living in Miguel Pereira (2/36), Nova Friburgo (2/36), Petrópolis (7/36) and Teresópolis (25/36), which are towns located in the mountainous region of the state of Rio de Janeiro, with a tropical higher-altitude climate and mean annual temperature of $18.5^{\circ} \mathrm{C}$ (CLIMATE-DATA.ORG, 2017), and $871 \mathrm{~m}$ altitude (TERESÓPOLIS, 2017).

Blood samples from 36 dogs attended at private practice and submitted to a commercial laboratory (VetLab Análises Clínicas Veterinárias Ltda.) were evaluated for piroplasms and hematological disorders using light microscopy and molecular analysis. Complete blood counts $(\mathrm{CBC})$ were assessed using an automatic counter (ABX Micros ABC Vet; Horiba ABX, USA). Buffy coat smears were stained by quick-stain procedures (Instant-Prove ${ }^{\circledR}$ ) for hemoparasite screening.

The clinical signs of 24 out of the 36 dogs in the study were evaluated during appointments or hospitalization at private practice.

\section{DNA extraction, amplification and sequencing}

Blood samples were collected in tubes containing 10\% EDTA and frozen at $-20^{\circ} \mathrm{C}$. DNA extraction was done using the Illustra Blood Genomicprep kit (GE Healthcare), in accordance with the manufacturer's directions.

Forward primer Bab 143-167 (5'-CCG TGC TAA TTG TAG GGC TAA TAC A-3') and reverse primer Bab 858-834 (5'-CCT CTG ACA GTT AAA TAC GAA TGC C-3') were used in the PCR reaction, which amplified fragments of approximately $700 \mathrm{bp}$ from the gene that encodes the $18 \mathrm{~S}$ region of piroplasm RNA (SOARES et al., 2011; LEMOS et al., 2012).

The amplicons were purified using the PureLink ${ }^{\mathrm{TM}}$ PCR Purification commercial kit (Invitrogen ${ }^{\circledR}$, Carlsbad, CA, USA), in accordance with the manufacturer's instructions, and then were sequenced using the ABI Prism 3130 automatic sequencer.

\section{Phylogenetic analysis}

The sequences obtained by amplifying the $18 \mathrm{~S}$ rRNA gene fragment and then sequencing with the primers $B A B$ 143-167 and BAB 858-834 were compared and aligned with those available in GenBank, using the BLAST software for identity assessment. Genetic similarity trees were built using the Neighbor-Joining method, using the Mega 6.06 software (TAMURA et al., 2013). For phylogenetic comparisons, the following $18 \mathrm{~S}$ rRNA gene sequences were included in the alignment: Rangelia vitalii (JN880430.1, KT288203.1, KF218606.1), Babesia motasi (AY260179.1), B. ovata (AY603400.1), B. gibsoni (KF878947.1), B. vogeli (AY371195.1), B. canis (AY072926.1), B. rossi (DQ111760.1), Babesia sp. Coco (EU109716.1), Theileria annae (AF188001.1), 
B. bigemina (X59607.1), B. caballi (AB734386.1), B. microti (U09833.1), T. equi (Z15105.1), T. parva (L02366.1), T. annulata (EU083801.1), Cytauxzoon felis (GU903911.1) and Plasmodium falciparum (AY579419.1).

\section{Results}

\section{Light microscopy}

Twenty-seven out of the 36 dogs (27/36) were found to be positive for piroplasms by lighy microscopy. Two out of $27(2 / 27)$ positive samples $(7.4 \%)$ originated from Miguel Pereira, while 7.4\% (2/27) were from Nova Friburgo, 25.9\% (7/27) were from Petropolis and $59.3 \%(16 / 27)$ were from Teresopolis. Intraerythrocytic and intraleukocytic parasites and free-living parasites in the plasma were observed in blood smear from circulating blood (Figure 1). There was variation of parasite morphology, with oval, piriformis, amoeboid, solitary, paired, grouped and basophilic forms.

\section{PCR and sequencing}

Using the primers Bab 143-167 and Bab 858-834, fragments of approximately $700 \mathrm{bp}$ from the gene that encodes the $18 \mathrm{~S}$ rRNA region of piroplasms were obtained in PCR assays. The primers used in this study amplify other canine piroplasms and identification of
R. vitalii was only possible by genetic sequencing (SOARES et al., 2011; LEMOS et al., 2012). DNA sequencing was performed on the 36 samples that were found to be positive in PCR assays. The blood samples from 36 animals included in this study were confirmed to be positive for $R$. vitalii by genetic sequencing. The samples thus sequenced were deposited in GenBank with the following accession numbers: KU710762.1 to KU710797.1.

When comparing the obtained sequences with those deposited in GenBank, the samples were found to be $99 \%$ identical to R. vitalii samples from Argentina (KF218606.1), Rio de Janeiro, Brazil (JN880430.1), and Passo Fundo, Brazil (KT288203.1). The genetic similarity tree (Figure 2) based on $18 \mathrm{~S}$ rRNA gene showed that the $R$. vitalii sequence (KU710762.1) grouped with R. vitalii from Argentina (KF218606.1) and Brazil (JN880430.1, KT288203.1).

Sequence analysis from the 36 samples of this study revealed $100 \%$ of identity between 25 samples. There was a difference in only one nucleotide in ten samples. Eight (8/10) of these samples (KU710762.1, KU710763.1, KU710765.1, KU710769.1, KU710778.1, KU710793.1, KU710794.1 e KU710795.1) had substitution of one nucleotide in the same site, while two samples (2/10) (KU710783.1, KU710789.1) had a difference of one nucleotide in different sites. One sample (KU710766.1) had substitution of two nucleotides in its sequence.

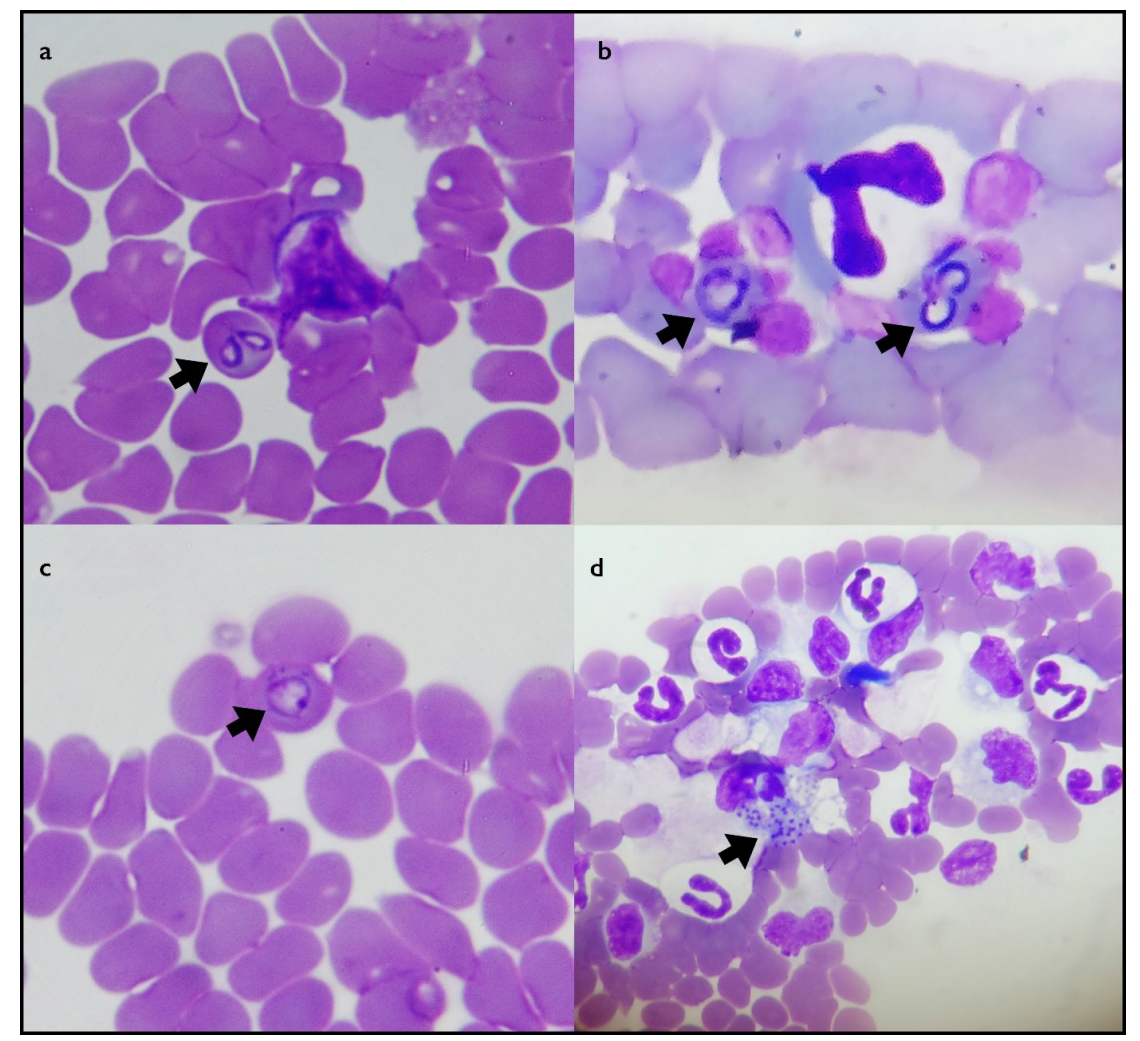

Figure 1. Peripheral blood smears from dogs naturally infected by piroplasms: (a, b, c) arrows indicating intraerythrocytic Rangelia vitalii merozoites (diagnosed by means of PCR and sequencing) from naturally infected dogs; (d) arrow indicating $R$. vitalii merozoites (diagnosed by means of PCR and sequencing) adjacent to canine leukocyte. Immersion microscopy (1000x). Stained using Instant-Prov, NewProv. 


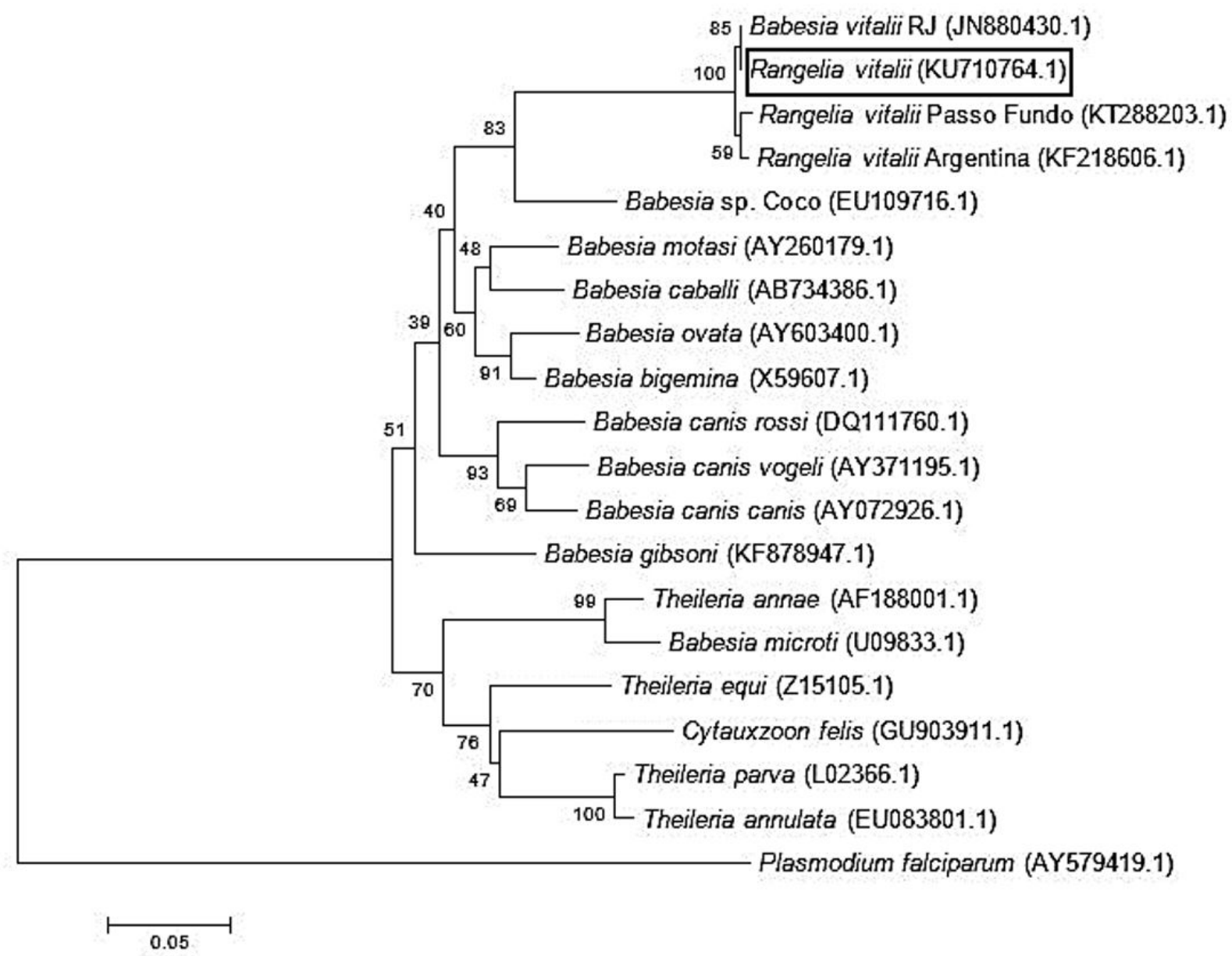

Figure 2. Neighbor-Joining tree (Tamura-Nei model) based on the partial 18S rRNA gene sequence of Rangelia vitalii (KU710764.1) detected in Rio de Janeiro and on similar sequences from GenBank. Bootstrap values were obtained after 1000 resamplings. The new sequence is marked by a rectangle. The outgroup used in this work was Plasmodium falciparum (AY579419.1).

\section{Hematological disorders}

Thirty-two out of 36 dogs of the study (88.9\%) presented anemia. Normocytic normochromic anemia was observed in $72.2 \%$ of the samples (26/36), macrocytic normochromic anemia in $11.1 \%(4 / 36)$, macrocytic hypochromic in $2.7 \%(1 / 36)$ and normocytic hypochromic in $2.7 \%(1 / 36)$. Through reticulocyte analysis, $33.3 \%$ of the animals (12/36) were found to present regenerative anemia, while $55.5 \%$ (20/36) presented non-regenerative anemia. Anisocytosis and/or polychromasia were observed in $83.3 \%$ (30/36) and metarubricytes in $16.6 \%(6 / 36)$ of the dogs with rangeliosis. In this study, normocytic normochromic anemia was seen together with anisocytosis and/or polychromasia in $83.3 \%$ (30/36) of the positive dogs.

Leukograms on the $R$. vitalii-positive animals showed leukopenia in $19.4 \%$ (7/36) and leukocytosis in $22.2 \%$ (8/36). Leukocytosis with a left shift was observed in $16.6 \%(6 / 36)$ of the animals, and $8.3 \%(3 / 36)$ of the cases presented a left shift without leukocytosis. There was monocytosis in $38.8 \%$ (14/36) of the dogs. $11.1 \%$ (4/36) and 25\% (9/36) of the dogs presented lymphocytosis and lymphopenia, respectively. Blood smear evaluations revealed that
$63.8 \%(23 / 36)$ of the dogs with rangeliosis presented activated monocytes and $30.5 \%(11 / 36)$ had reactive lymphocytes.

In this study, $97.2 \%(35 / 36)$ of the $R$. vitalii-infected animals presented thrombocytopenia.

\section{Clinical signs}

Clinical evaluations were performed on 24 animals in this study. A variety of clinical signs were observed: apathy and prostration $(87.5 \%-21 / 24)$; fever above $38.5^{\circ} \mathrm{C}(75 \%-18 / 24)$; bleeding from ears, paws or nose $(41.6 \%-10 / 24)$; diarrhea (41.6\% - 10/24); anorexia (37.5\% - 9/24); pale mucosae $(37.5 \%$ - 9/24); splenomegaly (29.1\% - 7/24); melena (20.8\% - 5/24); abdominal pain (20.8\% - 5/24); hyporexia (16.6\% - 4/24); vomiting $(16.6 \%$ - 4/24); icteric mucosae $(12.5 \%-3 / 24)$ and dehydration (4.1\% - 1/24). Among these 24 dogs, 16.6\% (4/24) died.

Among the 24 dogs presenting clinical signs, 66.6\% (16/24) showed parasites in blood smear evaluations.

Ten dogs presented hemorrhage in some place, such as the ear, paw, nose or dorsal region (Figures 3 and 4). Among these 


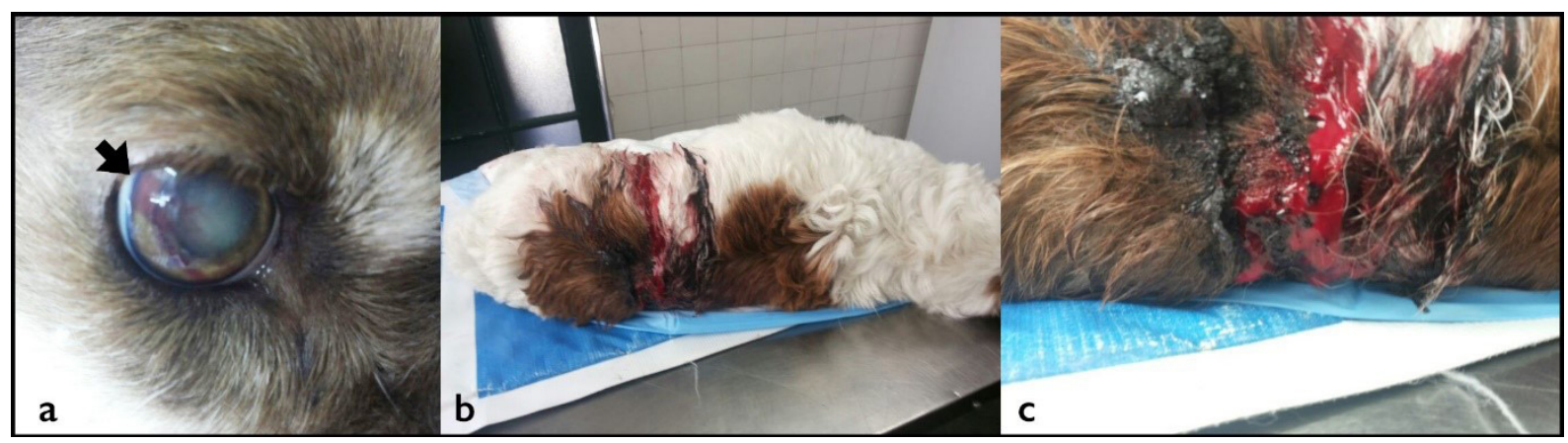

Figure 3. Natural infection due to Rangelia vitalii in a crossbred dog: (a) arrow indicating hyphemia; (b) dorsal region bleeding; (c) dorsal region bleeding in detail.

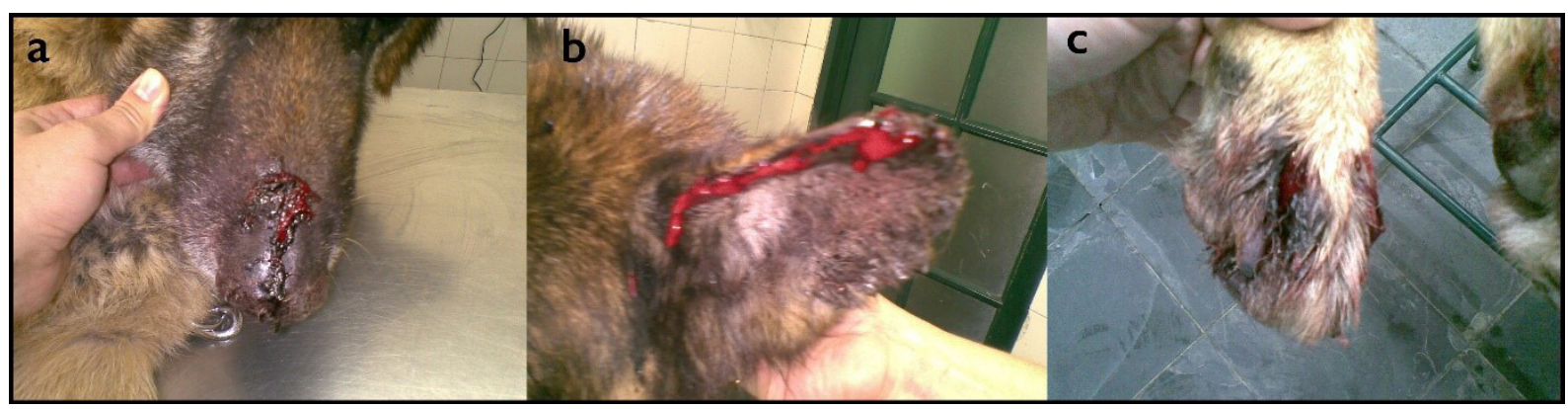

Figure 4. Natural infection due to Rangelia vitalii in a German Shepard dog. Spontaneous bleeding in (a) nasal plane; (b) pinnae; and (c) limb.

ten dogs, no piroplasms were found in blood smear evaluations in $50 \%(5 / 10)$ of the cases. One dog with spontaneous hemorrhage from the ear was the only one with platelets within the normal reference limits (175.000 cells/ $\mu \mathrm{L})$. Hemorrhagic diarrhea and/or melena was observed in $25 \%(6 / 24)$ of the infected animals.

\section{Discussion}

In the present study, the parasite morphology assessed by smear evaluations on circulating blood was compatible with the large piroplasm species described in dogs (PESTANA, 1910b; SHORTT, 1973; DUARTE et al., 2008; SOARES et al., 2011). Rangelia vitalii and Babesia vogeli are morphologically indistinguishable, and species differentiation is done by PCR and genetic sequencing (LEMOS et al., 2012).

The phylogenetic tree demonstrated that the sample from this study (KU710762.1) and the R. vitalii samples from Rio de Janeiro, Brazil (JN880430.1); Passo Fundo, Brazil (KT288203.1) and Argentina (KF218606.1) form a new branch of piroplasms. This conclusion is supported by the high bootstrap value of this phylogenetic analysis. The bootstrap values were obtained after 1000 resampling.

Presence of regenerative anemia with reticulocytes, anisocytosis, polychromasia and metarubricytes has been a consistent finding regarding canine rangeliosis (PESTANA, 1910b; CARINI \& MACIEL, 1914; FIGHERA et al., 2010; FRANÇA et al., 2010, 2013). This is consistent with the hemolytic condition caused by the parasite. Immune-mediated hemolytic anemia (IMHA) with spherocytes is commonly associated with canine rangeliosis (LORETTI \&
BARROS, 2005). In this study, the presence of non-regenerative anemia in a large number of the $R$. vitalii-infected animals (20/36) was an uncommon finding in comparison with the data in the literature. This finding can be related to host immune competence, acute-phase infection or immune-mediated bone marrow depression, in which there is specific antibody production against erythroid lineages. There may be polychromatophilic red blood cell destruction or immature erythrocyte precursors (THRALL, 2007; COWGILL et al., 2003).

Leukogram in $R$. vitalii-infected dogs can vary, and both leukopenia and leukocytosis can affect dogs (FIGHERA et al., 2010; FRANÇA et al., 2010). Leukopenia associated with neutropenia and eosinopenia may be related to the acute phase of infection (FRANÇA et al., 2013).

The exoerythrocytic cycle presented by $R$. vitalii can cause lesions in many tissues, thus resulting in circulating cells with phagocytic properties, such as macrophages (LORETTI \& BARROS, 2005; FIGHERA et al., 2010). This may explain the increase in the number of macrophages and activated monocytes in peripheral circulation in the CBC of the dogs of this study. Monocytosis associated with decreased numbers of parasites in the peripheral circulation was reported from an experimental study (FRANÇA et al., 2013). Macrophages are responsible for normal red blood cell destruction and for phagocyte-parasitized erythrocytes and complex microorganisms, including parasites (BUENO et al., 2005; THRALL, 2007). When phagocytosis is required, infected dogs may present increased numbers of monocytes, even in tissues, where these cells turn into macrophages (BUENO et al., 2005).

Reactive lymphocytes in circulation are related to antigenic stimulation (SCHULTZE, 2010). There is a strong 
immune-mediated reaction caused by circulating parasites in rangeliosis. Reactive lymphocytes and activated monocytes with phagocytic properties are frequently seen in blood smears (FIGHERA et al., 2010).

In this study, thrombocytopenia was the most consistent finding in the CBC. Only one animal had platelets within the normal reference limits $(175,000$ cells/ $\mu \mathrm{L})$. This uncommon result from the platelet count may be related to individual immune competence. Thrombocytopenia is a very common finding in rangeliosis (FIGHERA et al., 2010; PAIM et al., 2012b). It is believed to occur due to mechanisms such as splenic sequestrum, immune-mediated thrombocytopenia, vasculopathy, consumption thrombocytopenia, and platelet dysfunction (FIGHERA et al., 2010; PAIM et al., 2012b; FRANÇA et al., 2014). In a study on experimental $R$. vitalii infection, it was observed that there was a decrease in platelet aggregation and presence of thrombocytopenia, which were not due to bone marrow depression, since there was increase in megakaryocytes (FRANÇA et al., 2013).

The clinical signs presented by affected animals in this study were consistent with what had previously been described, such as prostration, anorexia and fever as the first ones observed in dogs with rangeliosis (PESTANA, 1910a, b; CARINI \& MACIEL, 1914; FIGHERA et al., 2010). Loretti \& Barros (2005) reported the presence of pale mucosae, jaundice, dehydration, fever, weight loss, weakness, lymphadenomegaly and splenomegaly. In a study by Fighera et al. (2010), the main clinical signs in dogs that were naturally infected with $R$. vitalii were slight to severe jaundice (100\%), signs of gastroenteritis (60\%), vomiting (34.3\%) and hemorrhage $(28.6 \%)$. According to a study carried out by Silva et al. (2011), dogs that were experimentally infected with $R$. vitalii presented fever, increased heart rate, apathy and anorexia. Weight loss and diarrhea were less frequent.

In this study, jaundice was observed in three animals (3/24). From comparisons with data in the literature, it is the most frequent characteristic of dogs with rangeliosis (LORETTI \& BARROS, 2005; FIGHERA et al., 2010). In some reports, jaundice has been observed, mainly in puppies and in the final phase of the disease (PESTANA, 1910a; CARINI \& MACIEL, 1914). In our study, the three icteric animals were adults, and one died.

High numbers of icteric animals have been seen, especially in reports on necropsy findings (FIGHERA et al., 2010). This confirms the suspicion that jaundice is seen in the final phase of the disease. Jaundice in rangeliosis is probably associated with IMHA and is clinically detectable when bilirubin is over $1.5 \mathrm{mg} / \mathrm{dL}$. Conjugated bilirubin is the main cause of tissue jaundice in dogs. Hyperbilirubinemia is a characteristic of IMHA, although it does not occur in all cases, and its absence does not rule out the possibility of IMHA (NELSON \& COUTO, 2010).

Hemorrhage in dogs with rangeliosis is frequently documented and may be characterized by acute gastroenteritis and cutaneous bleeding from the ears, nose and skin. Cutaneous hemorrhage is considered to be characteristic sign of canine rangeliosis, and it is important regarding differentiation between rangeliosis and other forms of piroplasmosis (PESTANA, 1910b; BRAGA, 1935; FRANÇA et al., 2014). Although uncommon, some dogs may have platelet counts within normal limits, in spite of spontaneous bleeding (LORETTI \& BARROS, 2005). Hemorrhage can be explained by platelet aggregation caused by increased extracellular adenosine (PAIM et al., 2012a, b). Parasites are not viewed during the hemorrhagic phase of dogs presenting rangeliosis, but are more easily seen during the first days of infection and during fever peaks (PESTANA, 1910b).

One of the dogs that died became hypothermic and hypotensive just before death. This is frequently observed among $R$. vitalii-affected animals during the final phase of the disease (PESTANA, 1910a). This same dog had a wound on the dorsum that presented severe bleeding a few hours before death, and it also had hyphema.

\section{Conclusion}

Rangelia vitalii is morphologically identical to other piroplasms such as Babesia vogeli and differentiation between these species is only possible by molecular detection (PCR and sequencing).

The most frequent clinical disorders among $R$. vitalii naturally infected-dogs were fever, spontaneous cutaneous bleeding and diarrhea.

Regenerative anemia and jaundice are frequently reported among dogs with rangeliosis. Nevertheless, in this study, these disorders were only observed in a small number of animals, while normocytic and normochromic non-regenerative anemia and thrombocytopenia were the most common hematological disorders in $R$. vitalii-positive dogs and therefore should be considered in hematological evaluations in suspected cases.

\section{Acknowledgements}

We would like to thank the Coordination Office for Improvement of Higher-Education Personnel (Coordenação de Aperfeiçoamento de Pessoal de Nível Superior. CAPES), Carlos Chagas Filho Research Support Foundation of the State of Rio de Janeiro (Fundação Carlos Chagas Filho de Amparo à Pesquisa do Estado do Rio de Janeiro, FAPERJ) and the National Council for Scientific and Technological Development (Conselho Nacional de Desenvolvimento Científico e Tecnológico, CNPq) for the financial support for this study.

\section{References}

Braga A. Contribuição ao estudo diferencial das piroplasmoses dos cães. Bol Vet Exército 1935; 3: 1-16.

Bueno R, Mello MN, Menezes CAS, Dutra WO, Santos RL. Phenotypic, functional, and quantitative characterization of canine peripheral blood monocyte-derived macrophages. Mem Inst Oswaldo Cruz 2005; 100(5): 521-524.

Carini A, Maciel J. Sobre a molestia dos cães, chamada Nambi-uvú e o seu parasita (Rangellia vitalii). An Paul Med Cir 1914; 3(2): 65-71.

Climate-Data.org. Dados climáticos para cidades mundiais [online]. Oedheim: AM Online Projects; 2017 [cited 2017 February 1]. Available from: https://pt.climate-data.org

Cowgill ES, Neel JA, Grindem CB. Clinical application of reticulocyte counts in dogs and cats. Vet Clin North Am Small Anim Pract 2003 33(6): 1223-1244. 
Duarte SC, Louly CCB, Silveira OJ No, Romanowski TNA, Lino RS Jr, Linhares GFC. Diagnóstico parasitológico e molecular da babesiose canina na cidade de Goiânia - GO. Rev Patol Trop 2008; 37(3): 229-236.

Eiras DF, Craviotto MB, Baneth G, Moré G. First report of Rangelia vitalii infection (canine rangeliosis) in Argentina. Parasitol Int 2014; 63(5): 729-734.

Fighera RA, Souza TM, Kommers GG, Irigoyen LF, Barros CSL. Patogênese e achados clínicos, hematológicos e anatomopatológicos da infecção por Rangelia vitalii em 35 cães (1985-2009). Pesq Vet Bras 2010; 30(11): 974-987.

Fighera RA. Rangeliose. Acta Sci Vet 2007; 35(S2): 261-263.

França RT, Silva AS, Costa MM, Paim FC, Soares JF, Labruna MB, et al. Hematologic and bone marrow changes in dogs experimentally infected with Rangelia vitalii. Vet Clin Pathol 2013; 42(1): 31-39.

França RT, Silva AS, Loretti AP, Mazzanti CM, Lopes ST. Canine rangeliosis due to Rangelia vitalii: from first report in Brazil in 1910 to current day: a review. Ticks Tick Borne Dis 2014; 5(5): 466-474.

França RT, Silva AS, Paim FC, Costa MM, Soares JF, Mazzanti CM, et al. Rangelia vitalii in dogs in southern Brazil. Comp Clin Pathol 2010; 19(4): 383-387.

Lemos TD, Cerqueira AM, Toma HK, Silva AV, Corrêa RG, Paludo GR, et al. Detection and molecular characterization of piroplasms species from naturally infected dogs in southeast Brazil. Rev Bras Parasitol Vet 2012; 21(2): 137-142.

Loretti AP, Barros SS. Hemorrhagic disease in dogs infected with an unclassified intraendothelial piroplasm in southern Brazil. Vet Parasitol 2005; 134(3-4): 193-213.

Loretti AP, Barros SS. Parasitismo por Rangelia vitalii em cães ("nambiuvư", "peste de sangue") - uma revisão crítica sobre o assunto. Arq Inst Biol 2004; 71(1): 101-131.

Nelson RW, Couto CG. Medicina interna de pequenos animais. Rio de Janeiro: Elsevier; 2010.

Paim CB, Paim FC, Silva AS, França RT, Costa MM, Leal CAM, et al. Thrombocytopenia and platelet activity in dogs experimentally infected with Rangelia vitalii. Vet Parasitol 2012b; 185(2-4): 131-137.

Paim CB, Silva AS, Paim FC, França RT, Costa MM, Souza VC, et al. Activities of ectonucleotidases and adenosine deaminase in platelets of dogs experimentally infected with Rangelia vitalii. Exp Parasitol 2012a; 131(2): 252-257.

Pestana BRO. Nambyuvú (nota preliminar). Rev Soc Cie São Paulo 1910a; V: 14-17.

Pestana BRO. O nambiuvú. Rev Méd São Paulo 1910b; (22): 423-426.

Pocai EA, Frozza L, Headley AS, Graça DL. Leishmaniose visceral (Calazar): cinco casos em cães de Santa Maria, Rio Grande do Sul, Brasil. Cienc Rural 1998; 28(3): 501-505.

Quadros RM, Soares JF, Xavier JS, Pilati C, Costa JL, Miotto BA, et al. Natural Infection of the Wild Canid Lycalopex gymnocercus by the Protozoan Rangelia vitalii, the Agent of Canine Rangeliosis. J Wildl Dis 2015; 51(3): 787-789.

Schultze AE. Interpretation of canine leukocyte responses. In: Weiss DJ, Wardrop JK. Schalm's veterinary hematology. 6th ed. Wiley-Blackwell; 2010. p. 321-334.

Shortt HE. Babesia canis: the life cycle and laboratory maintenance in its arthropod and mammalian hosts. Int J Parasitol 1973; 3(2): 119-148.

Silva AS, França RT, Costa MM, Paim CB, Paim FC, Dornelles GL, et al. Experimental infection with Rangelia vitalii in dogs: acute phase, parasitemia, biological cycle, clinical-pathological aspects and treatment. Exp Parasitol 2011; 128(4): 347-352.

Soares JF, Carvalho L, Maya L, Dutra F, Venzal JM, Labruna MB. Molecular detection of Rangelia vitalii in domestic dogs from Uruguay. Vet Parasitol 2015; 210(1-2): 98-101.

Soares JF, Dall'agnol B, Costa FB, Krawczak FS, Comerlato AT, Rossato BC, et al. Natural infection of the wild canid, Cerdocyon thous, with the piroplasmid Rangelia vitalii in Brazil. Vet Parasitol 2014; 202(3-4): 156-163.

Soares JF, Girotto A, Brandão PE, Silva AS, França RT, Lopes STA, et al. Detection and molecular characterization of a canine piroplasm from Brazil. Vet Parasitol 2011; 180(3-4): 203-208.

Tamura K, Stecher G, Peterson D, Filipski A, Kumar S. MEGA6: Molecular Evolutionary Genetics Analysis version 6.0. Mol Biol Evol 2013; 30(12): 2725-2729.

Teresópolis. Prefeitura Municipal. A cidade [online]. Teresópolis: ASCOMTV; 2017 [cited 2017 April 28]. Available from: http://www. teresopolis.rj.gov.br/a-cidade

Thrall MA. Hematologia e Bioquimica Clínica Veterinária. São Paulo: Roca; 2007. 